\title{
Innovative Rice Seed Coating (Oryza Sativa) with Polymer Nanofibres and Microparticles Using the Electrospinning Method
}

\author{
Letícia M.F. Castañeda ${ }^{a, b}$, Cayane Genro ${ }^{a}$, Isabel Roggia ${ }^{a}$, Stefan S. Bender ${ }^{a, b}$, \\ Renar J. Bender ${ }^{\mathrm{b}}$ and Cláudio N. Pereira ${ }^{\mathrm{a},{ }^{*}}$ \\ ${ }^{a}$ Tecnano Pesquisas e Serviços Ltda. Porto Alegre - RS - Brazil, Rua Washington Luiz, 675/1117, \\ 90010.460, Porto Alegre - RS, Brazil \\ ${ }^{b}$ Faculty of Agronomy, Federal University of Rio Grande do Sul. Av. Bento Gonçalves, 7712, 91540.000, \\ Porto Alegre, RS, Brazil
}

\begin{abstract}
Seed treatments are chemical or biological substances that are applied to seeds to control infection by disease-causing organisms, insects, or other pests. Seed treatment reduces production costs of seedlings, reduces the consumption of seeds, facilitates mechanization of sowing and improves the seedling establishment. The generation of nanofibres and microcapsules by the electrospinning technique is a novel approach for active ingredient controlled release. The study evaluates an innovative rice seed coating (Oryza sativa) with polymer nanofibres and microparticles using this method.

Materials and Methods: Polymer nanofibres and microcapsules were applied by the electrospinning technique to irrigated rice seeds. The treatments consisted of: 1) Control, 2) Negative control - Polymer based microcapsule without fungicide. 3) Polymer based microcapsule with fungicide. Microbiological assays and germination tests were performed following the guidelines of the Seed Analysis Rules of the Ministry of Agriculture.
\end{abstract}

Results: The applied polymer as a coating did not affect the physiological quality of the seeds, as attested by the result of the germination tests, and they proved to be effective in the control of fungi disease in crop seeds.

Conclusion: The germination and phytosanitary characteristics were improved in the analyzed study.

Keywords: Seed treatment, polymer, electrospinning, nanofibres, microcapsules.

\section{INTRODUCTION}

Seed treatments consist of chemical or biological substances that are applied to seeds to control infection by disease-causing organisms, insects, or other pests. Seed treatment reduces production costs of seedlings, reduces the consumption of seeds, facilitates mechanization of sowing and provides improvements for seed and seedling establishment by incorporating nutrients, growth regulators and other agrochemicals. Seed treatment provides protection during the critical germination and vigour establishment stages when the seed and emerging seedlings are unable to protect themselves from invasive pathogens [1-4]. Serving as the first line of defense for seeds and seedlings, seed treatments can improve seed germination, seedling emergence, stand establishment and plant vigour [5]. As a result of this early season performance, plants treated with seed treatments have an advantage over untreated plants when it comes to realizing yield, quality and profit potential. Use of agrochemical encapsulated compositions are especially interesting in situations when effective

*Address correspondence to this author at the Tecnano Pesquisas e Servicos Ltda. Porto Alegre - RS - Brazil, Rua Washington Luiz, 675/1117, 90010.460, Porto Alegre - RS, Brazil; Tel: 55 (51) 3287-2150;

E-mail: claudio@tecnano.com.br activity of the encapsulated ingredient over a longer period of time, typically several weeks, is necessary as it is released into the environment continuously in the required amount rather than in one large initial dose. Since its introduction, seed treatment has been considered as an efficient and cost-effective approach for crop establishment.

Controlled release encapsulated agrochemicals are particularly important for use as pre-emergent pesticides wherein they are applied to the soil prior to the emergence of vegetation or the appearance of insects. By such application, they are available over a period of time to kill or control newly emerged weed species or insects in their larval stages.

Despite these advantages, according to some authors', applied conventional agrochemicals still have limitations in the production of the desired biological response at the precise time and in the precise required quantities [6]. Besides this limitation, actual applied controlled release formulation has advantages, some of which are: 1) prolongation of activity over a long period; 2) reduced number of necessary applications; 3) cost reduction; 4) environment pollution reduction by reducing undesirable side effects of agrochemical losses by evaporation and degradation or leaching by rain into the soil or waterways; 5) 
converting technical pesticide liquid into solid formulation, resulting in easily transported material with reduction of flammability.

A novel approach using nanotechnology was recently introduced by Lal and colleagues (2012) [7]. It is a seed coating in which systemic pesticides were incorporated into a biodegradable nano-polymer system and coated on the surface of seeds using the electrospinning/ electrospraying process with the aim of improving the delivery system of the pesticide by controlled-release mechanism.

Utilizing this nanotechnology approach, this paper describes the rice seed coating (Oryza sativa) with polymer nanofibres incorporating commercial, active agrochemical ingredients. Nanofibres and microparticles were generated by the electrospinning or electrospraying technique.

The study has evaluated the quality, germination and phytosanitary characteristics of irrigated rice seeds for establishing the efficacy of the strategy.

\section{MATERIALS AND METHODS}

Seed coating based on ethyl cellulose, incorporating the suspension concentrate systemic and contact fungicide Vitavax Thiram SC-200® (Chemtura Indústria Química do Brasil Limitada, containing Carboxin 20\% $\mathrm{m} / \mathrm{v}$, Thiram $20 \% \mathrm{~m} / \mathrm{v}$, and Ethylene glycol $24,9 \% \mathrm{~m} / \mathrm{v}$, inerts $50,7 \% \mathrm{~m} / \mathrm{v}$ ) or the systemic fungicide Carbex 500 SC $\circledast$ (Nortox S.A, containing carbendazim $50 \% \mathrm{~m} / \mathrm{v}$, inert $50 \% \mathrm{~m} / \mathrm{v}$ ) were applied to the seed surface as nanofibres and microparticles. Ethyl cellulose polymer with a viscosity of $4 \mathrm{cP} 5 \%$ in toluene/ethanol 80:20 (lit.) and $48 \%$ ethoxy content, was purchased from Sigma-Aldrich Co. The solvents dichloromethane, ethanol, N,N-dimethyl formamide were purchased from Labsynth Ltda. De-ionized water was produced at the laboratory. Different polymer concentrations were used, ranging from 4 to $10 \%(\mathrm{w} / \mathrm{v})$ of ethyl cellulose in solvent mix. Using the electrospinning syringe, the polymer ethyl cellulose, aniline dye and fungicide were applied in the form of a solution of a polymer in organic solvents to the seeds and deposited in the collector in the form of a thin film. This electrospinning apparatus consists of a high voltage (HV) supply, a needle connected to the $\mathrm{HV}$, a syringe pump and an electrified metal collector.

The seed treatments consisted of: 1) Control, 2) Negative control - nanofibres or particles without fungicide. 3) Cases - Polymer based nanofibre microcapsule with thiram fungicide. Both the negative control and the cases were applied electrostatically to the seed surface with a $30 \mathrm{kV}$ voltage and a distance of $16 \mathrm{~cm}$ (needle tip-to-collector) in an electrospinning apparatus.

Electrospinning apparatus. A custom made electrospinning machine with a $60 \mathrm{kV} \mathrm{HV}$ supply was used. The syringe pump consisted of $3 \mathrm{~mL}$ syringes.

Electrospinning pre-mix. The solution of EC dissolved in the binary solvent mix was homogenized in a magnetic stirrer overnight. The solution was fed into the electrospinning machine with a syringe pump at a rate of $0.05 \mathrm{ml} / \mathrm{min}$ using a $3 \mathrm{~mL}$ syringe with a blunted needle (BD Precision Glide 22G). A $1.81 \mathrm{kV} / \mathrm{cm}$ voltage difference was applied between the nozzle and collector where the nanofibre film was deposited.

The seeds treated with antifungal substance were subjected to germination and plant health. Germination test and phytosanitary characteristics of the seeds was carried out following the norms of RAS (Rules Analysis seeds) of the Ministry of Agriculture [8], with 400 seeds, using sub-samples of 100 seeds for treatment on a piece of germitest paper dampened with distilled water at 2.5 times the dry weight of the paper. The rolls of paper were placed in BOD incubators regulated to the ideal temperature of $25^{\circ} \mathrm{C}$. Counting was performed after fourteen days. The results were expressed by percentage.

The results of the germination test are used to compare the physiological quality of a number of lots to determine the rate of sowing and serve as a parameter for marketing of the seeds. Thus, the test is performed following standardized methodology under controlled artificial laboratory conditions, highly favorable for obtaining the highest percentage of germination in the shortest time possible.

Sanitary quality of seeds: this was made using the method of filter paper ("blotter test") for detection of fungi on seeds. Bottom germitest gearboxes, with previously coated paper, were moistened with sterile distilled water, using eight replicates of 25 seeds, totalling 200 seeds per sample. Following this, the boxes containing the seeds were incubated in a controlled environment $\left(20^{\circ} \mathrm{C}\right)$ with alternating 12 hours of darkness and 12 hours of light. After seven days, the standard incubation period, the seeds were evaluated individually and microorganisms were identified and 


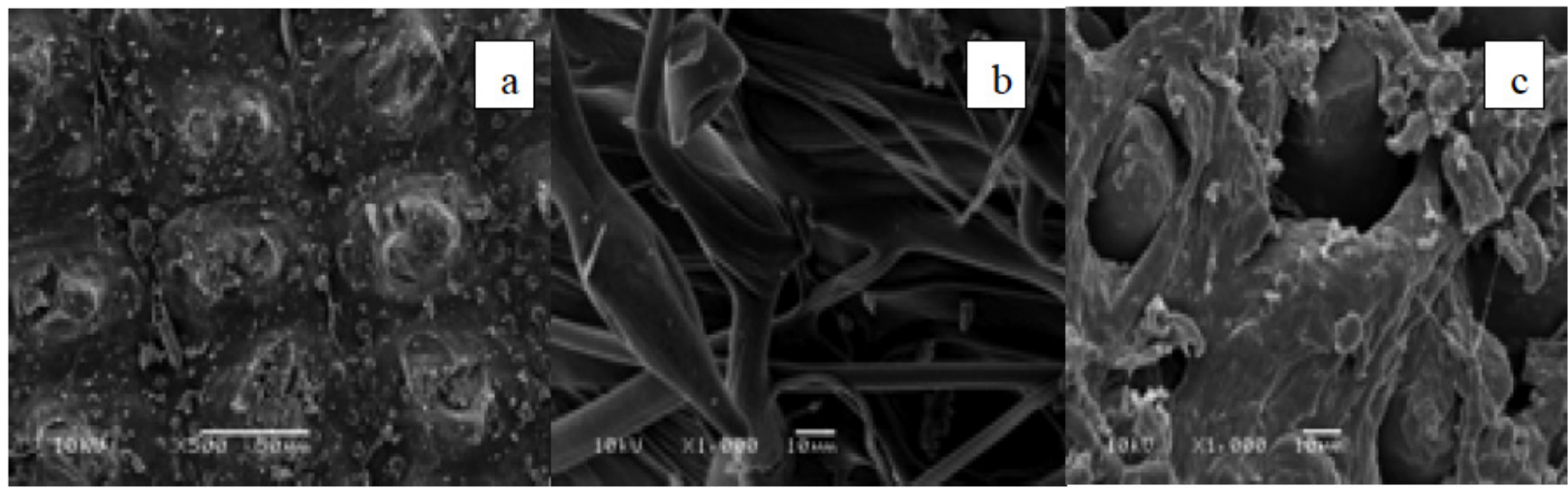

Figure 1: Optical micrographs of the uncoated Oryza sativa rice seed surface (a) and coated rice seed surface (b and c). Tecnano, Porto Alegre. RS. 2012.

quantified. Identification was made based on the shape and colour of sporulation.

The films were analysed by scanning electron microscopy (SEM) (JEOL JSM 6060) equipment. The samples were deposited directly onto an aluminum support (stub). The samples settled in the aluminum blocks and were then metalized with gold and visualized under the microscope at $10 \mathrm{kv}$ with 1.000 magnification.

\section{RESULTS}

Germination. When the seeds were subjected to the germination test, the coating did not affect the rice seed germination rates (maintaining them above 92\%) (Table 1, Figure 2B). These results are in agreement with Pires and colleagues [9], Oliveira and colleagues [10], Pereira and Oliveira [11] and Silva and colleagues [12] who also found that the percentage of germination was not reduced by the coating but only the rate of germination. Bays and colleagues [13] observed that coating the seeds with polymer did not affect the physiological quality of the seeds. Binneck and colleagues [14] studied the effect of coating on the germination and emergence of seeds of white clover and concluded that the use of coated seeds can produce populations with high rates of germination and seedling emergence.

Table 1: Average Germination of Rice (Oryza Sativa)

\begin{tabular}{|c|c|}
\hline Treatment & Germination (\%) \\
\hline \hline Control & $87 \mathrm{~B}$ \\
\hline Seed coating + Vitavax ${ }^{\circ}$ & $95 \mathrm{~A}$ \\
\hline Seed coating + Carbex $®$ & $93.38 \mathrm{~A}$ \\
\hline
\end{tabular}

*Average followed by the same capital letter in the columns does not differ significantly $(P<0.05)$ by Tukey test.
Coating appearance. The seed coating with fungicides provides seeds with a good appearance, polymer adherence to the seed surface substrate, even distribution on the seed surface and staining. The presence of the film coating on the seed surface was confirmed by scanning electron microscopy (SEM) images, which showed the coating in the form of nanofibres or microcapsules, which had adhered to the seed surface.

The SEM images showed that the polymer had adhered to the rice seed surface (Figure 1). To the left (a), the rice surface without polymer, in the centre of the image (b), nanofibres deposited on the seed surface and to the right (c), a film (fused fibres) also deposited on the surface. Some beads are also shown in image (b), which are round or fuse-like and inside the fibres, which contributes to making the fibres near them larger.

Phytosanitary characteristics. The application of the fungicide reduced the incidence of fungi in the case of the irrigated rice (Table 2) when comparing the seed coated with fungicide applied by the electrospinning machine with the positive control.

As can be seen in Table 2, the Carbex® treatment was more efficient than the Vitavax® in this study. This could be because of the resistance of the microorganisms to the fungicide but also because of the more stable formulation developed.

The fungicide microcapsule kept the pathogen arrested, showing that it is even more effective (Figure 2A) when comparing the product with the positive control (seed coating without fungicide), as was expected. 
Table 2: Percentage of Infected Seeds in Phytosanity Testing of Irrigated Rice (Oryza Sativa). T1: control, T2: Seed coating + Vitavax $\AA$, T3: Seed coating + Carbex ${ }^{\circledR} .2012$

\begin{tabular}{|c|c|c|c|}
\hline Treatment & Fusarium (\%) & Aspergillus (\%) & Penicillium (\%) \\
\hline \hline T1 & $8.48 \mathrm{~A}$ & $7 \mathrm{~A}$ & $5.4 \mathrm{~A}$ \\
\hline T2 & $3.72 \mathrm{AB}$ & $0 \mathrm{~B}$ & $1.52 \mathrm{~B}$ \\
\hline T3 & $2.72 \mathrm{~B}$ & $0 \mathrm{~B}$ & $0 \mathrm{~B}$ \\
\hline
\end{tabular}

${ }^{*}$ Average followed by the same capital letter in the columns does not differ significantly $(P<0.05)$ by Tukey.
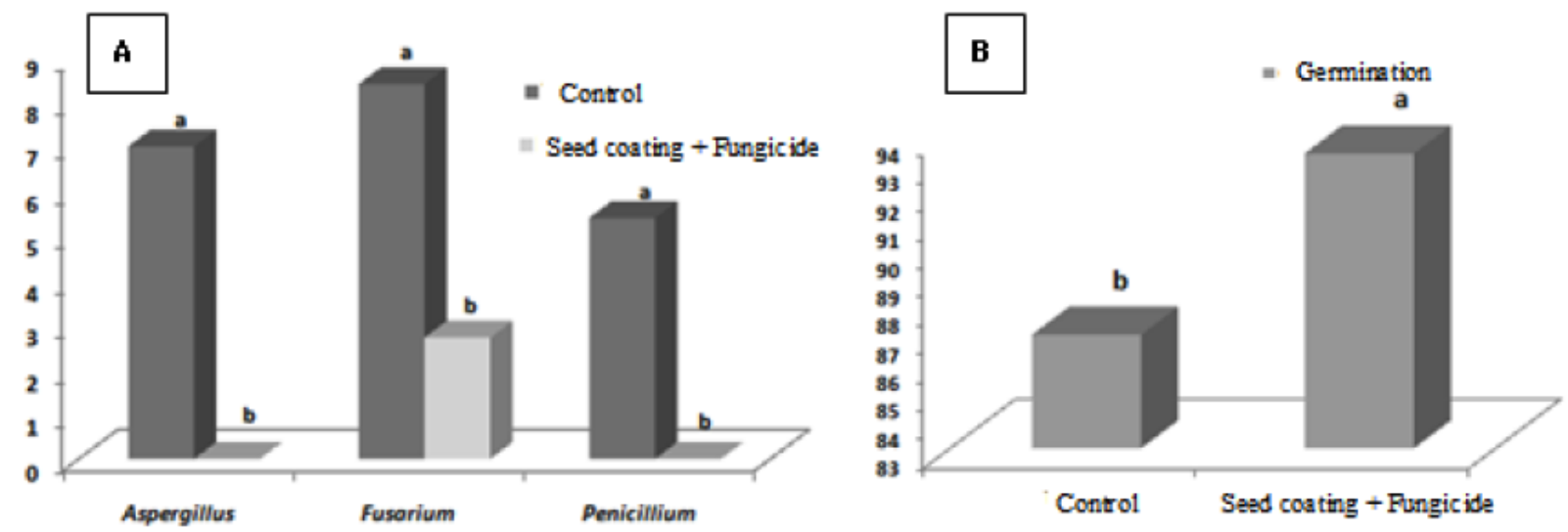

Figure 2: Incidence (\%) of disease caused by fungi: Aspergillus, Fusarium, Penicillium. (A) germination (\%) of seeds from irrigated rice (Oryza sativa) (B).

Averages followed by the same lower case letters do not differ statistically by Tukey test.

\section{DISCUSSION}

Electrospinning is a very versatile and effective technology for obtaining continuous polymer fibres with a diameter ranging from a few nanometers to micron nanometers [15]. Electrospinning and electrospraying are used for making polymeric nano-microfibres and nano-microparticles, respectively, for a variety of applications. According to Lal and colleagues (2012) [7], by virtue of their nanoscale diameter and very large surface area, electrospinning/ electrospraying offer a number of additional advantages, like enhanced bioavailability of the pesticides, improved specificity, improvement of the timed release of pesticide molecules and ease and safety in handling.

In the present study, nanofibres incorporating the fungicide carboxin- thiram and carbendazim, were applied as a seed coating. The parameters which have been evaluated are germination test and the phytosanitary characteristics of irrigated rice seeds. The vigour is the attribute that gives the seed the ability to germinate, emerge and quickly result in normal seedlings under a wide range of environmental conditions; attributes which are not made manifest by only the germination test, which determines the germination percentage [16]. Along with these determinations, the analysis of the sanitary quality can assist in the selection of the agrochemical to be used in each case. The importance of seed health is in the fact that approximately $90 \%$ of crops used for food, both human and animal, are propagated by seeds and the inoculums present in them may result in the increase of disease in the field and its introduction into areas free of pathogens [17].

It was found that seeds coated with fungicide by electrospinning/ electrospraying techniques showed a germination percentage higher than the non-treated seeds. According to Machado (2000), this result was the consequence of the fungicidal efficacy of the eradication of the fungi [18]. The assigned lower incidence of fungi on treated seeds, whether pathogenic or not, prevented the harmful effects of fungi on the seed quality. Schuch and colleagues [19] evaluated the chemical effect by using different concentrations of fungicide for the physiological and sanitary quality of the rice seeds for a period of six months storage in airtight containers. They concluded that seed treatment with fungicide Carboxin - thiram at a dose of $300 \mathrm{ml}$ per $100 \mathrm{~kg}$ of seeds resulted in a 
higher germination percentage for the evaluation performed immediately after treatment, reducing the incidence of Fusarium spp.; Alternaria spp.; Gerlachia sp.; Dreschlera spp.; Curvularia sp.; Phoma sp. in irrigated rice.

The germination test of the present study showed that the coating did not affect the rice seed germination rates, keeping them above $92 \%$. These results are similar to those achieved by Lal and colleagues (2012) [7] which showed that the seed coating process by electrospinning and electrospraying did not affected the germination of seeds in both wheat and cotton. In that study, systemic pesticides were incorporated into a biodegradable nanoscale polymer system. They achieved $100 \%$ seed germination on all coated seeds in $96 \mathrm{~h}$ of observation. The polymer systems used were PLA and PLGA, resulting in nanofibres or particles, both using the same electrohydrodynamic technique. Both polymer systems, that used by Lal and co-workers using biodegradable polyesters and the present system, using a renewable source polymer, are considered eco-friendly approaches and are therefore important for agriculture purposes.

The germination obtained was satisfactory in that it was observed that germination was affected positively with higher germination than the minimum established for the marketing of rice, which is $80 \%$, according to the Rules for Seed Analysis [8].

The seed treatment achieved fungi control in the irrigated rice seeds with emphasis on the fungi which has a higher incidence in stored seeds: Penicillium, Fusarium and Aspergillus. The fungi penicillium and aspergillus showed no significant difference between treatments with fungicide carboxin- thiram and carbendazim, both being considered effective in combatting these fungi, commonly found in storage conditions.

With regard to the fungus fusarium, it was established that treatment with carbendazim was the most effective, when compared to the control. This could be because of the application method of the polymer or the type of fungicide used.

This result shows the potential of the application. The applied polymer as a coating did not affect the physiological quality of the seed, as attested by the result of the germination tests; a fact of extreme importance for future work utilizing the incorporation of active seed protecting agents.
Shape of fibres and particles. The authors Yang and colleagues [15] investigated the effects of solvents, including dichloromethane (MC), ethanol, N,Ndimethylformamide (DMF) and mixtures of solvents in the morphology and diameter of PVP nanofibres obtained by electrospinning. The 4\% PVP nanofibres obtained by the electrospinning technique from simple ethanol solutions were smooth, whereas the nanofibres from the DMF and MC structures exhibited beads-onstrings. In solvent mixture systems, a mixture of ethanol/ DMF, with a mass ratio of 50/50, was selected as a good solvent for producing PVP nanofibres with diameters as small as $20 \mathrm{~nm}$. In a solvent mixture, such as PVP, the concentration was increased from 4 to $8 \%$ by weight, and the fibre diameter increased from 20 to $50 \mathrm{~nm}$. In the case in hand, microparticles and fibres ranging from nanoscale to microscale were also found. Some fibres showed a bead-like appearance, more specifically fuse-like (Figure $\mathbf{1 b}$ ). At a higher concentration than a threshold, called entanglement concentration $\left(\mathrm{C}_{\mathrm{e}}\right)$, overlapping of the polymer chains favours entanglement, which gives rise to a much stronger interaction and so leads to smooth fibres rather than particles [20]. This result was related to the physicochemical properties of both the polymer and the solvents utilized.

It is known that physicochemical properties, such as dielectric constant, boiling point, surface tension and viscosity of the polymer solution are important factors to define the morphological characteristics of the nanofibres generated. The polymer concentration and molecular weight of the polymer is also related to the latter property. Thin and uniform nanofibres were produced by electrospinning by Chuangchote and colleagues [21] from PVP solutions in solvents with a significantly high dielectric constant, low surface tension and low viscosity.

The nanofibres and particles images of the seed coating presented in this paper show nanofibres and some beads deposited on the seed surface and also some round or fuse-like fibres. These types of fibres or particles, like the cited beads, are commonly seen by researchers experienced with electrospinning and electrospraying techniques. The fibres or particles achieved are related to the physicochemical parameters of the polymeric solution or the machine apparatus used. The higher concentrations leads to fibres and lower concentrations tend to produce particles. The fuse-like fibres are in relation to intermediary results or they can be related to the wet- 
spinning condition, when the solvent has not been totally evaporated before reaching the fibre collector. The applied voltage, distance from syringe to collector and dielectric constant of the solution are among others parameters related to the resulting fibre appearance, but not to all of them. For comparison purposes, Lal and colleagues (2012) [7] reports that the size of spun fibres obtained ranged from $130 \mathrm{~nm}$ to $210 \mathrm{~nm}$ in diameter and the coating thickness ranged from 18.6 $\mu \mathrm{m}$ to $20.49 \mu \mathrm{m}$ on the seeds.

The application of the fungicide by the nanotechnology approach in the present study reduced the incidence of fungi in the case of the irrigated rice. This could be because of the resistance of the microorganisms but also because of the formulation developed. These are preliminary results that need to be further investigated to formulate a proposal that this methodology has an advantage in comparison with current methods. Kinetics studies should be made to determine whether the nanofibres or particles achieve better controlled release of the agrochemical molecules.

Besides establishing the efficiency of competitive advantages, another challenge yet to be met is the upscaling of a nanotechnology approach, opening the way for its utilization by seed industries in an economical and competitive way. This is yet to be achieved, but in recent years, industrial grade electrospinning has begun to reach the commercial market.

Another problem that has not been solved until now by the state-of-the-art in seed treatment is that there is no efficient method for adhering the bacteria, fungicide and insecticide onto the seeds all at once because the bacteria inoculant cannot be protected from being harmed by the fungicides used in the seed treatment. The encapsulation of the active ingredients may be able to reduce this problem. Recently, the authors related the successful encapsulation of rizhobia inoculant into nanofibres using the same technology [22]. These results represent an advance for a better protection of seeds while preserving the symbiotic inoculation bacteria in the seed treatment process.

These positive germination and phytosanitary results, although preliminary, are encouraging for further developing the approach and for determining the vigour and controlled release of the method in future studies.

\section{CONCLUSION}

Ethyl cellulose nanofibres were applied by the electrospinning technique to irrigated rice seeds. The applied polymer as a coating did not affect the physiological quality of the seeds, as attested by the result of the germination tests; a fact of extreme importance for future work utilizing the incorporation of active seed protecting agents. The seed coating proved to be effective in the control of fungi disease in crop seeds. The germination and phytosanitary characteristics were improved in the analyzed study. This innovative process holds promise for future applications in the fields of agrochemical controlled release.

\section{ACKNOWLEDGEMENTS}

Acknowledgements to CNPq (Conselho Nacional de Desenvolvimento Científico e Tecnológico), FAPERGS (Fundação de Amparo à Pesquisa do Estado do Rio Grande do Sul) and FINEP (Financiadora de Estudo e Projetos) for financial support.

\section{REFERENCES}

[1] Haynes JG, Pill WG, Evans TA. Seed treatments improve the germination and seedling emergence of switchgrass (Panicum virgatum L.). Hort Sci 1997; 32(7): 1222-26.

[2] Buxton DR, Melick PJ, Patterson LL, Godinez CA. Evaluation of seed treatments to enhance cotton seedling emergence. Agron J 1977; 69: 672-76. http://dx.doi.org/10.2134/agronj1977.0002196200690004003 $\underline{7 x}$

[3] Thomas TH. Seed treatments and techniques to improve germination. Scientia Hortic 1981; 32: 47-59.

[4] West SH, Loftin SK, Wahl M, Batich CD, Beatty CL. Polymers as moisture barriers to maintain seed quality. Crop Sci 1985; 25: 941-44. http://dx.doi.org/10.2135/cropsci1985.0011183X0025000600 $\underline{10 \mathrm{x}}$

[5] Lorini I, Krzyzanowski FC, França Neto JB, Henning AA Principais Pragas e Métodos de Controle em Sementes durante o Armazenamento - Série Sementes. Londrina: Embrapa Soja, 12p, 2010. (Circular Técnica. Embrapa Soja. ISSN 1516-7860, n. 73).

[6] Saurabh D, Vishal J, Patanjali PK. J Sci Ind Res India 2011; 70(2): 105-12.

[7] Lal A, Gupta K, Tyagi V, Yadav S. Anonymous. Annual Report of the National Bureau of Plant Genetic. Resources 2011-2012, NBPGR, Pusa Campus, New Delhi, India 2012; p. 213.

[8] Brasil. Regras para análise de sementes (RAS) /Ministério da Agricultura, Pecuária e Abastecimento. Secretaria de Defesa Agropecuária. Brasília e MAPA/ACS, 2009; p. 399.

[9] Pires LL, Bragantini C, Costa JLS. Armazenamento de sementes de feijão revestidas com polímeros e tratadas com fungicidas. Pesqui Agropec Bras 2004; 39(7): 709-15. http://dx.doi.org/10.1590/S0100-204X2004000700013

[10] Oliveira JA, Pereira CE, Guimarães RM, Vieira AR, Silva JBC. Desempenho de sementes de pimentão revestidas 
com diferentes materiais. Rev Bras Sementes 2003; 25(2): 36-47.

http://dx.doi.org/10.1590/S0101-31222003000400006

[11] Pereira CE, Oliveira JA. Qualidade Fisiológica e Sanitária de sementes de Brachiaria decumbens revestidas e tratadas com inseticida e fungicida. Londrina-PR: Informativo ABRATES 2003; 13(3): 227.

[12] Silva JBC, Santos PEC, Nascimento WM. Desempenho de sementes peletizadas de alface em função do material cimentante e da temperatura de secagem dos péletes. Hortic Bras 2002; 20(1): 67-70. http://dx.doi.org/10.1590/S0102-05362002000100013

[13] Bays R, Baudet L, Henning AA, Lucca Filho. O Recobrimento de sementes de soja com micronutrientes, fungicida e polímero. Rev Bras Sementes 2007; 29(2): 6067.

http://dx.doi.org/10.1590/S0101-31222007000200009

[14] Binneck E, Barros ACSA, Vahl LC. Peletização e aplicação de molibdênio em sementes de trevo-branco. Rev Bras Sementes 1999; 21(2): 203-207.

[15] Yang Q, LI Z, Hong Y, Zhao Y, Qiu S, Wang C, Wei Y. Influence of Solvents on the Formation of Ultrathin Uniform Poly(vinyl pyrrolidone) Nanofibres with Electrospinning. J Polym Sci Part B: Polym Phys 2004; 42(20): 3721-26. http://dx.doi.org/10.1002/polb.20222

[16] Marcos Filho J. Teste de envelhecimento acelerado. In: Krzyzanowski FC; Vieira RD; França-Neto, JB (Ed.). Vigor de sementes: conceitos e testes. Londrina-PR: Informativo ABRATES 1999; 1-24.

[17] Henning AA. Patologia e tratamento de sementes: noções gerais. Londrina: Embrapa Soja, 51p, 2004. (Documentos. Embrapa Soja, ISSN 1516-781X, n. 235).

[18] Machado JC. Tratamento de sementes no controle de doenças. LAPS/UFLA/FAEPE, Lavras - MG 2000; p. 138.

[19] Schuch JZ, Lucca Filho OA, Peske ST, Dutra LMC, Brancão MF, Rosenthal MD. Qualidade fisiológica e sanitária de sementes de arroz com diferentes graus de umidade e tratadas com fungicida. Rev Bras Sementes 2006; 28(1): 4553.

http://dx.doi.org/10.1590/S0101-31222006000100007

[20] Haas D, Heinrich S, Greil P. J Mater Sci 2010; 45: 1299-306. http://dx.doi.org/10.1007/s10853-009-4082-7

[21] Chuangchote S, Sagawa T, Yoshikawa S. Electrospinning of poly(vinyl pyrrolidone): Effects of solvents on electrospinnability for the fabrication of poly(p-phenylene vinylene) and $\mathrm{TiO}_{2}$ nanofibres. J Appl Polym Sci 2009; 114: 2777-91.

http://dx.doi.org/10.1002/app.30637

[22] Damasceno RG, Roggia I, Pereira CN, Saccol Sá E. Rhizobia survival in seeds coated with polyvinyl alcohol (PVA) electrospun nanofibres. Can J Microbiol 2013; 59(11): 716-19.

http://dx.doi.org/10.1139/cjm-2013-0508

(C) 2014 Castañeda et al.; Licensee Lifescience Global.

This is an open access article licensed under the terms of the Creative Commons Attribution Non-Commercial License (http://creativecommons.org/licenses/by-nc/3.0/) which permits unrestricted, non-commercial use, distribution and reproduction in any medium, provided the work is properly cited. 